\title{
Conceptual Framework for a Curriculum in Social Change
}

\author{
Iris M. Yob \\ Walden University
}

Colleges, universities, and many high schools are expressing their mission in terms of creating social change or contributing to the common good. Such a mission suggests that if they are going to graduate students who will fulfill this mission, they will need to consider how they will best prepare students to do this. The conceptual framework for a curriculum in social change in this article offers a holistic approach, taking into account what a student should know, be able to do, and what values and attitudes should be nurtured. To that end, the article identifies three competencies in the knowledge domain (scholarship, systemic thinking, and reflection), four in the skills domain (application, advocacy, collaboration, and political engagement), and three in the affective domain (ethics, commitment, and courage). Each of the competencies is supported by theory and illustrated in practice.

Keywords: knowledge, skills, attitudes, values, social change, curriculum

\section{Introduction}

Universities and colleges are deliberately describing their mission in terms of promoting the common good and contributing to positive social change-from Boston University (n.d.) in the Northeast United States, which proclaimed, "Changing the world is part of our identity" (para 1); to the Midwest, where Indiana University Bloomington (2018) announced that its "educational experiences change the lives of [its] graduates-and the lives of the communities they serve as experts and professionals" (para 3); to Stanford University (2017) in the West, which identifies among its purposes "to promote the public welfare by exercising an influence in behalf of humanity and civilization" (para 4). Although there are cultural differences in the motivation for social change and the context for becoming engaged (Yob, 2016), institutions of higher education around the world have embraced similar purposes and missions.

Today, promoting the common good is expressed not only in terms of pushing out the boundaries of knowledge and providing an educated workforce for the professions, economic development, scientific progress, and societal leadership, but it has also come to mean directly addressing the issues and challenges that characterize communities and societies today. Social problems, economic challenges and opportunities, and environmental issues have all become part of the higher education sphere of research and service. Wherever these efforts are found, Boyer's (1990) dream of scholarship reconsidered is being realized. This is "rethinking education: towards the common good" as United Nations Educational, Scientific, and Cultural Organization (2015) envisioned it.

Fundamentally, we can assert that if we want learners to effect social change now and after they graduate, educators need to ensure their learners know how to do it. What knowledge, skills, and attitudes should they develop to be effective agents of social change?

I am indebted to the members of a task force at Walden University for responding to the early draft of this framework: Darragh Callahan, Elizabeth Wilson, Ian Birdsall, Gary Carson, Stephanie Ford, and Karen Ouzts. 
In this article, I will suggest 10 competencies that can provide the conceptual framework for curriculum building for social change: three in the knowledge domain (scholarship, systemic thinking, and reflection), four in the skills domain (application, advocacy, collaboration, and political engagement), and three in the affective domain (ethics, commitment, and courage). There are likely other competencies, but this elaboration can serve as a starting point. In real life, many of these competencies merge with and complement others, but at least on a theoretical level, they are sufficiently discrete to merit our attention. Importantly, each of them can be recognized and developed as elements in a social change agent's repertoire.

\section{Knowledge Domain}

In this domain, the attention is on what learners should know and how they should think when involved in social change. It encompasses interpretation, meaning-making, critical thinking, judging, and creative imagination. Educational institutions are particularly well suited to developing these elements, giving them an essential role to play in promoting the common good.

\section{Scholarship}

In this context, scholarship is understood broadly to include both what a learner takes from other scholars as well as what she offers in the way of new findings. In the former, she delves critically into relevant theories and current research so she can approach a challenge or opportunity well informed. In the latter, armed with appropriate research methodology and tools, she discovers fresh perspectives and insights that can suggest new actions or lines of inquiry (see, e.g., Balakas \& Sparks, 2010; O'Brien 2008). Breunig (2010) went so far as to say that the precursors to focused social change action are theory and research; without these, social change activity can be aimless, merely reflexive, and random. Data-based evidence and critical theoretical analysis, she suggested, can take practice beyond "easy' and quick solutions, inferences, assumptions and intuition" (p. 258). These sentiments are echoes of what Kant (1781/1993) recognized when he declared, "intuitions without concepts [are] blind" (p. 69).

Bernie Turner serves as an example here. He was working full time in various political action campaigns in New York, New York, when he had the opportunity to enroll in university courses. In an unpublished article he wrote at the time, "Macro: Social Change, a Variation on a Theme" (Turner, n.d.), he grappled with the concept of anomie ("a state in which previous norms are no longer applicable," p. 1) proposed by Durkheim (1897/1951). This theoretical construct was influential in his thinking from that time on. Armed with this idea, he and his wife, Rita, founded a unique kind of university whose mission would be to create positive social change. The institution challenged the status quo in higher education at the time in what was studied, who studied, and how they studied (Keller, 2009, Sect IV). Not only was the institution creating anomie among institutions but it was graduating students who would also create anomie. Today, in their 90s, the Turners continue to pursue their anomie project through the Center for Critical Thinking, a discussion group made up of key thinkers that tackles current social problems. Based on a critical grasp of a theory of social change, the trajectory of their lives of community activism became more focused, enduring, and far reaching.

\section{Systemic Thinking}

Most of the problems facing society are multifaceted; that is, they arise from multiple causes, have multiple manifestations, and produce multiple effects, and so require multifaceted solutions. Much of society can be understood through its power structures-who holds power and who is powerless- 
and those power structures can influence every aspect of the lives of all in that society. Wealth, gender, and race are key determinants of power. This is true whether we are looking at problems of discrimination, homelessness, violence, environmental degradation, employment, underperforming schools, corruption, sexual assault, or access to healthcare, universally or locally. Not tackling these problems holistically may mean making little progress toward a permanent solution. But, tackling any one of these problems holistically is overwhelming for any individual or team of workers. Seeing a problem in its broad context, however, may help social change agents attack a problem on its many fronts or at least prioritize their efforts while ameliorating the effects of what they cannot deal with.

Even on a smaller scale, more immediate and local problems can have many dimensions. This is exemplified in a service-learning course in the Louisiana State University honors program, which focused on the human response to disaster and disease. Just a few weeks into the course, Hurricane Gustav swept through, damaging the campus and surrounding areas and providing an immediate service-learning opportunity for the participants. With professors from architecture, disaster management, social work, coastal environmental studies, and education - coupled with readings from business, environmental science, geography, sociology, public health, oceanography, and human ecology and the results of analyzing data gathered in questionnaires designed and deployed by the class members - students in this course gained a wide and deep understanding of the many factors involved in that kind of natural disaster (Plummer, Buchanan, Barrett Kennedy, Rouse \& Pine, 2011). On this basis, they had the information needed to provide guidelines for action that could inclusively and systematically be put to work in the aftermath of the storm.

\section{Reflection}

Thinking things through is fundamental to effective action. It occurs at all stages of social change activity, from grasping the dimensions and even urgency of an issue, to planning a response to it and enacting that plan. If reflection does not occur at the beginning of the process, learners may not be persuaded that an issue is worthy of their effort and attention or that a practical response can be found. During the process itself, learners need to be aware of the reasons behind their action for it to carry meaning for them. But, it is in the final stages of the process that reflection has a particularly significant part to play; for here, learners are able to confront and resolve the disequilibrium that the encounter with the issue might have caused them. They probably encountered sights, smells, and sounds that were foreign to them. They were likely disturbed by the encounter. This is the moment when one's thinking can be restructured and deep learning can take place (Maddux \& Donnett, 2015). It is tempting, however, for active agents of social change to put their energies into the doing and not stop to reflect about that doing, and so a critical moment for doing better and learning more can be lost.

Because a social change project involves multiple groups of individuals-the social change agents, the community members, collaborating partners, the student supervisors-all should be involved in postproject reflection activities, individually and/or collectively. Learners should hear the responses of those they worked with and for, as well as engage in self-reflection on their own contribution, their role on the team, the results of their activity, and how their thinking might have changed.

\section{Skills Domain}

This domain enumerates the practical abilities that might be found in the inventory for agents of social change. It has to do with what agents can do. Certain personalities will be drawn to some more than others, and certain situations will require some skills and not others. In this conceptual 
framework, the skills described here are higher order and demand critical judgement, reflection, and the backing of sound scholarship.

\section{Application}

As noted earlier, Kant (1781/1993) had criticized blind intuitions, but his full statement was "Thoughts without content are empty; intuitions without concepts, blind" (p. 69). He went on to say, "Neither of these faculties can exchange its proper function. Understanding cannot intuit, and the sensible faculty cannot think. In no other way than from the united operation of both, can knowledge arise" (p. 69). In other words, for an education in social change, engagement with the real world and scholarship are different sides of the same coin, and both should be attended to. This theme is taken up by Dewey, who argued that practical experience coupled with reflection was the key not only to learning but also to a democracy in which learners have a social responsibility (e.g., Dewey, 1933, 1938/1963). Freire was also of this mind when he described a path to social justice taking the road of praxis: theory and personal experience interacting to produce a sense of empowerment that can lead to change (e.g., Freire, 1970, 1976).

In social change preparation, experiential approaches to learning have been very successful. Servicelearning courses in high school and undergraduate programs, which connect what is studied in class with working on real-world problems in the community, have a 3-decade history now and substantial literature that provides evidence of their powerful impact on learners. This includes, for instance, studies that found that service-learning increased a student's engagement with the community outside of the university, their greater understanding of issues and problems in the community, a deeper appreciation of and ability to relate to cultural and racial difference, an enhanced belief in their ability to make a difference, a profounder commitment to community service, and a stronger tendency to choose helping careers (Gallini \& Moely, 2003) and student retention (Yob, 2014).

In master's-degree programs, social change activity has often been through service-learning projects related to master's course work and, in some cases, has taken the form of minor research projects, such as needs assessment studies that have provided data to inform practical projects (e.g., master of science in public policy at New York University Wagner, n.d.). Doctoral degree programs are even more focused on developing research skills and can find application to social change in the evaluation of practical projects, collecting data to generate a theory of social change or a model of social change practice. In professional doctorates, such as those in education, business, social work, nurse practitioner, clinical psychology, and so on, a wider array of acceptable research methodologies in action research may be available and may permit more deliberate connection with the practice of the profession.

\section{Advocacy}

Advocacy is essentially an educative undertaking, one that intends to both raise awareness around an issue and also elicit an empathetic response to it. In a study of social interventions by nonprofits, Shier and Handy (2015) developed a typology of advocacy approaches that includes two main thrusts: first, creating public awareness through education initiatives, community engagement, and changing public perceptions and second, influencing policy direction through bringing information forward to policy makers, undertaking research, and through discussions in networks of local and state service providers.

In its narrowest sense, advocacy means being "the voice for the disenfranchised and oppressed" (Chang, Hays, \& Milliken, 2009, p. 28) Building on this definition, Chang et al. suggested five steps professional counselors may take in their advocacy role: providing critical information, serving as a 
mediator, negotiating for better services, lobbying, and guiding funding agencies. The essence of these steps may be generalized to other advocacy situations in which the role of the advocate is to speak on behalf of another. Social media, with its advantages and limitations, has become an important tool for advocacy (e.g., Guo \& Saxton, 2014).

Using a variety of strategies, the students at the Marjory Stoneman Douglas High School in Parkland, Florida, became advocates for gun control reform after a shooter killed 17 of their classmates on February 14, 2018 ("'39 days': How Parkland shooting survivors" 2018). Their efforts met public sentiment at a crucial time and garnered national and even international support. The follow-through on the passion and interest generated will be crucial in bringing about effective social change, but these students have provided the impetus through their advocacy.

\section{Collaboration}

When a change is viewed systemically in its larger social context, its multifacetedness becomes apparent. To meet this complexity and to multiply the efforts of a single individual, collaboration with others is essential. One cannot change the system alone.

There are many layers of collaboration and many interested parties to involve in a social change project. We can consider, first, the team one works with. A nursing student who worked with women who had been raped realized their need had many sides. They needed a responsive and empathetic team of first responders, so this student conducted classes with the fire department and police in the area and established with them the protocols for dealing with a rape victim sensitively and professionally. She also worked with law enforcement in strengthening their resolve to bring perpetrators to justice. The women also needed a trained hospital staff, so she instructed members in the local hospital on how to use rape kits. These efforts amounted to a team effort in dealing with the immediate response to a reported rape. As for the long-term effects on the victims themselves, she involved the local Suits for Success team in helping the women choose appropriate clothing for their protection and for job searching and the employment office in helping them get a job. These efforts were designed to restore a stronger sense of self-worth and self-assertiveness in the women for their future success and to live beyond the victimization that arose from the trauma they had experienced. The collaboration among these teams was the right response.

Second, collaboration extends also to the people we work for. In fact, these people become key players among those we work with. Systemic thinking can reveal our own complicity in the needs of othersour opportunities, backgrounds, and advantages may very well have come at a cost to others. Working with others can teach our students much about their own privilege in a society that does not provide an equal playing field for all. As this awareness grows, the agent of social change is himself changed.

Furthermore, those we are working for and with have perspectives that are essential if the activity is going to meet real needs. This becomes even clearer as the difference between the agent and the other grows wider. This is illustrated in the experience of a child advocacy organization in San Francisco, California (Lee, 2008). For 30 years, the organization had worked for families in the area and had achieved some remarkable goals, particularly in winning some important legislative actions that affected many. However, in the words of new leadership, they were not "liv[ing] up to their democratic promise or help[ing] to create the kind of systemic social change that poor children and their families need in the long term" (p. 69). She added, "We will increase funding for agencies to serve the poor but fail to end poverty. Our vision must be bigger, broader and bolder" (p. 69). The organization moved toward bringing together the board, staff, youth, and parent leaders for collective decision-making. The base of power moved to the working-class families in the area, many 
of whom were low income. The "highly inclusive planning process" clarified the organization's constituency, set the policy agenda, and refocused their efforts away from legislative action alone to affordable housing and public schooling, the two issues uppermost in the minds of the families involved. The empowerment of the community came from involving the community itself in shaping its own change.

Among the skills needed for effective collaboration, the list would include "civic skills, especially the ability to gather and interpret information; speak[ing] and listen[ing] cooperatively; dialogu[ing] effectively about differences; resolv[ing] conflicts; [and] reach[ing] agreements" (Levine, 2010, p. 5), all skills that can be learned and improved with practice and reflection.

\section{Political Engagement}

Levine (2010) reported that former President Obama rightly noted on his first day in office that "public engagement enhances the government's effectiveness and improves the quality of its decisions. Knowledge is widely dispersed in society, and public officials benefit from having access to that dispersed knowledge" (p. 5). The sentiments in the Levine report were elaborated in more detail in the call to action in A Crucible Moment: College Learning and Democracy's Future (National Task Force on Civic Learning and Democratic Engagement, 2012). Among the highlights of the task force's recommendations are two that relate particularly to the education of social change agents: fostering "progressively higher levels of civic knowledge, skills, examined values, and action" and developing political partnerships "locally, nationally, and globally" in addressing the common good (Association of American Colleges and Universities, n.d., p. 2).

While faculty and students might agree with the wisdom of such an education, there is some reticence in becoming politically engaged in an educational setting (Yob, 2013). Again, however, political engagement can also be broken down into specific, learnable skills: communicating research findings and proposing models for action; locating political leaders who could be involved in relevant legislation; finding and utilizing appropriate channels for communicating with legislators; becoming active in election campaigns; running for local, state, or national office; and so on. Serving on a policy committee is an opportunity to apply the political skills of making a case, persuading, forming alliances, and offering cost-effective, real solutions. Such committees are found in the workplace and in professional organizations as well as the political arena.

\section{Affective Domain}

This is the domain of attitudes, beliefs, and values. Faith, hope, a sense of calling, outrage at injustice, and feelings of guilt about one's privileged status in society all have their part to play in the world of feeling of the social change agent (Freire, 1997). At the simplest level, this domain has to do with open-mindedness and tolerance to consider a new value or position. This in turn can lead to some level of commitment, which in turn can grow from mere assent into support and appreciation and esteem and ultimately be expressed as a harmonious and consistent philosophy for living, internalized to the extent that one is characterized by it (Krathwohl, Bloom, \& Masia, 1964). Teaching in the affective domain is complicated and fraught with questions about whose values should be taught, but it is possible to identify some that relate specifically to the work of social change, values to be filled with appropriate content by the learner in context.

\section{Ethics}

Whenever human beings interact, ethics are involved. Ethics define appropriate behavior toward another and contribute to an individual's moral view of the world. The same considerations have also 
been extended to the nonhuman world of plants and animals in environmental ethics (Valentine, 2004). In the setting of social change, ethics play an important role, both in pointing out the unethical to be addressed and guiding relationships between the agent and her team members and others they are working with and for.

The particular ethics implicated in a social change project may need to be identified and agreed upon through a "dialogic and deliberative process" (Román, 2010, p. 130). In a more extreme situation, Román explored the challenge of working with disabled persons who may not have the capacity for such conversations. From here, he derived some fundamental ethical positions that can form a basis for ethics in other situations. Charity and beneficence, goodwill and paternalism may have been important in the past, but he saw them now as disempowering by making the caregiver (or social change agent) the center of the activity. Instead he placed in his list of ethical considerations reliance on "truthful knowledge" (evidence-based knowledge gleaned through the free exercise of research), impartiality and pluralism based on human rights, respect for the preferences of the individual (or his spokespersons) thus making the activity a coresponsibility, relevant professional and organizational ethics, quality care, empowerment and autonomy that respects the other's personal ethics, clear communication about intentions and purposes and personalizing the other. Such a list makes a good start to developing an appropriate ethical stance.

\section{Commitment}

Engagement in a long-term social change activity is sustained by the rational persuasiveness of theory, research, and ideals. But sometimes, that is not enough, especially when results do not meet expectations. In a service-learning course I was teaching, our community partner was the local homeless shelter. One of the homeless, a single mother, came to class to talk about her efforts to win back her three children, who had been taken from her by the courts. She had been perusing books in the university law library for legal advice when a couple of law students happened upon her. They admitted it would not be permissible for them to give her legal advice, but they would put bookmarks in relevant places and leave them for her on the shelves. Armed with the knowledge thus gained, the woman went back to court and secured the release of her eldest child into her care again. "Now," she told my class, "I want to earn my high school equivalency certificate so that I can get a job and convince the judge to return my other two children to me. I just need someone to coach me." One of the students in the class was more than eager to step in, so a date and time was set up when they would meet at the public library and begin lessons.

At the next class meeting, the student was rather downcast and admitted that the mother had not turned up at the appointed time. So, a new time was set. Again, the mother did not turn up. The student was beside herself with frustration. She totally bought into the mother's story and was willing to give her time and energy to helping her, and the woman was a no-show. The student vented her feelings in class, weeping loudly with sheer frustration. Fortunately, the director of the shelter was present and could explain to her and all of us that for many homeless people, there is a reason they are homeless, one that tells us much about who they are. Her homelessness was chronic, despite years of support and help. But, he added, despite a minimal success rate with getting individuals off homelessness, those who remain homeless still need our support and care. We just need to be there for them. Incidentally, the student wrote me a letter some years later to tell me she was working in the state department for families as a consequence of taking the course. Her commitment had been challenged by disappointment but she had renewed her dedication and found a career in the same kind of work. 
Among the factors that support a commitment to social change work are embeddedness in a network of common values and the opportunity to find the shared meaning in one's activity, that is, recognizing and using the objective and personally subjective aspects of the networks one works within (Passy \& Giugni, 2000).

\section{Courage}

Campos (2012) defined courage in the social change setting as "the physical, mental, or moral strength to risk adverse or negative consequences in choosing a just and responsible course of action" (p. 212). In an interview with the Turners, the activists who founded Walden University, it was clearly apparent that the social change work they had undertaken all their lives demanded high levels of courage. But starting up the university was perhaps the most courageous act of all. With a young family in tow, they moved from New York to Naples, Florida; risked every penny they had; and, with little evidence to bolster their optimism, sent out leaflets to potential students and hoped for the best. In an interview with them, I suggested that social change work today was fraught with danger, especially in a society where violence and guns seem to be escalating. "What if an activist gets shot?" I asked. Without a moment's hesitation, Bernie retorted, "Well, they get shot!"

Of course, nobody proposes that we send our learners into situations that are dangerous or life threatening, but everywhere, there is resistance to change. Activists may at the least be vilified, lose friends, damage longstanding relationships, or find it more difficult to get a job. It takes courage to become engaged in social change. And as Freire (1998) reminded us, engaging in social change can put our own cherished preconceptions and assumptions, our very sense of self, at risk as we encounter the other (pp. 41-43).

\section{Conclusion}

No particular order or hierarchy is implied in listing these 10 competencies. Some will be addressed as just-in-time learning when the learners are involved in a hands-on project; others can be included in course outcomes when the subject matter lends itself. The important thing to note is that social change activity is a holistic undertaking involving knowledge, skills, and values. When real people with all their thoughts, abilities, and feelings become engaged with promoting the common good, genuine change can take place in all those involved. Arming our learners for this kind of enterprise is itself a contribution to creating positive social change.

\section{References}

"39 days": How Parkland shooting survivors turned grief into action. (2018, March 24). CBS News. Retrieved from https://www.cbsnews.com/news/march-for-our-lives-39-days-how-parklandstudents-turned-grief-into-action/

Association of American Colleges and Universities. (n.d.). Highlights from A crucible moment: College learning and democracy's future: A report from the National Task Force on Civic Learning and Democratic Engagement. Retrieved from https://www.aacu.org/sites/default/files/files/crucible/highlights.pdf

Balakas, K., \& Sparks, L. (2010). Teaching research and evidence-based practice using a servicelearning approach, Journal of Nursing Education, 49, 691-695.

Boston University. (n.d.). A global BU. Retrieved from http://www.bu.edu/global/

Boyer, E. L. (1990). Scholarship reconsidered: Priorities of the professoriate. New York, NY: Carnegie Foundation for the Advancement of Teaching. 
Breunig, M. (2010). Research as experiential praxis. Journal of Experiential Education, 32, 257-260.

Campos L. (2012). Cultivating cultures of courage with transactional analysis. Transactional Analysis Journal, 42, 209-219.

Chang, C. Y., Hays, D. G., \& Milliken, T. F. (2009). Addressing social justice issues in supervision: A call for client and professional advocacy. Clinical Supervisor 28, 20-35. doi:10.1080/07325220902855144

Dewey, J. (1933). How we think: A restatement of the relation of reflective thinking to the educative process (revised ed.). Boston, MA: D. C. Heath.

Dewey, J. (1963). Experience and education. New York, NY: Collier Books. (Original work published 1938)

Durkheim, E. (1951). Suicide: A study in sociology. (J. Spaulding \& G. Simpson, Trans.) New York, NY: The Free Press. (Original work published in 1897)

Freire, P. (1970). Pedagogy of the oppressed. New York, NY: Continuum.

Freire, P. (1976). Education, the practice of freedom. London, United Kingdom: Writers and Readers Publishing Cooperative.

Freire, P. (1997). Pedagogy of the heart. New York, NY: Continuum.

Freire, P. (1998). Pedagogy of freedom: Ethics, democracy, and civic courage. Lanham, MD: Rowman and Littlefield.

Gallini, S., \& Moely, B. (2003). Service-learning and engagement, academic challenge, and retention. Michigan Journal of Community Service Learning, 10, 5-14.

Guo, C., \& Saxton, G. D. (2014). Tweeting social change: How social media are changing nonprofit advocacy. Nonprofit and Voluntary Sector Quarterly, 43, 57-79.

Indiana University Bloomington. (2018). The ideal college experience, two centuries in the making. Retrieved from https://www.indiana.edu/about/index.html

Kant, I. (1993) Critique of pure reason. London, United Kingdom: Everyman. (Original work published 1781)

Keller, W. (2009). Aspire toward the highest: Bernie and Rita Turner and the founding of Walden University. Marco Island, FL: Keller Publishing.

Krathwohl, D. R., Bloom, B. S., \& Masia, B. B. (1964). Taxonomy of educational objectives: Handbook II: Affective domain. New York, NY: David McKay.

Lee, N. (2008). Thirty years of advocacy in San Francisco: Lessons learned and the next generation of leadership. New Directions in Youth Development, 117, 61-75.

Levine, P. (2010). Strengthening our civic skills. The Public Manager, 39, 5-8.

Maddux, H. C., \& Donnett, D. (2015). John Dewey's pragmatism: Implications for reflection in service-learning. Michigan Journal of Community Service Learning, 21, 64-73.

National Task Force on Civic Learning and Democratic Engagement. (2012). A crucible moment: College learning and democracy's future. Washington, DC: Association of American Colleges and Universities.

New York University Wagner. (n.d.). Master of science in public policy. Retrieved from https://wagner.nyu.edu/education/degrees/master-science-public-policy 
O’Brien, F. (2008). In pursuit of African scholarship: Unpacking engagement. Higher Education, 58, $29-39$.

Passy, F., \& Guigni, M. (2000). Life-spheres, networks, and sustained participation in social movements: A phenomenological approach to political commitment. Sociological Forum, 15, $119-144$.

Plummer, C., Buchanan, T. K., Barrett Kennedy, C., Rouse, L., \& Pine, J. (2011). Broadening perspectives: A multidisciplinary collaborative teaching and learning experience. Journal of Community Engagement and Scholarship, 4, 60-69.

Román, B. (2010). Ethics in caregiving services for people with serious intellectual disabilities. Ramon Llull Journal of Applied Ethics, 1, 121-142.

Shier, M., \& Handy, F., (2015). From advocacy to social innovation: A typology of social change for nonprofits. Voluntas, 26, 2581-2603. doi:10.1007/s11266-014-9535-1

Stanford University. (2017). Stanford's mission. Retrieved from http://exploredegrees.stanford.edu/stanfordsmission/

Turner, B. (n.d.). Macro-social change: A variation on a theme. Unpublished manuscript.

United Nations Educational, Scientific, and Cultural Organization. (2015). Rethinking education: Towards a global common good? Paris, France: Author. Retrieved from http://unesdoc.unesco.org/images/0023/002325/232555e.pdf

Valentine, G. (2004). Geography and ethics: Questions of considerability and activism in environmental ethics. Progress in Human Geography, 28, 258-263.

Yob, I. M. (2013). Political engagement in higher education curricula. Journal of Social Change, 5, $1-10$.

Yob, I. M. (2014). Keeping students in by sending them out: Retention and service-learning. Higher Education Research Communications, 4, 38-57.

Yob, I. M. (2016). Cultural perspectives on social responsibility in higher education. Higher Education Research Communications, 5, 116-136. doi:10.18870/hlrc.v6i2.306

The Journal of Social Change, sponsored by Walden University, welcomes manuscripts focusing on interdisciplinary research in social change that improves the human condition and moves people, groups, organizations, cultures, and society toward a more positive future.

Walden University Publishing: http://www.publishing.waldenu.edu 